\title{
PENGARUH BEBAN KERJA DAN KONFLIK KERJA TERHADAP STRES KERJA KARYAWAN PT. AGRAPERSADA MEDAN
}

\author{
Dewi Budhiartini, SE,M.Si, Ph.D \\ Universitas Amir Hamzah \\ Budhidewi12@gmail.com
}

\begin{abstract}
Abstrak
Kebijakan perusahaan yang dilakukan dalam rangka meningkatkan produktivitas dan efisiensi kerja telah membawa akibat-akibat tertentu pada individu-individu yang terlibat dalam organisasi perusahaan. Individu-individu tersebut dituntut lebih banyak menciptakan keunggulan kompetitif melalui peningkatan pengetahuan, pengalaman, keahlian dan komitmen serta hubungan kebersamaan dengan rekan sekerja maupun dengan pihak lain di luar perusahaan. Stres merupakan topik yang menarik dan banyak mendapatkan perhatian dari banyak peneliti sumber daya manusia. Apabila dalam diri karyawan terjadi sebuah stres, maka hal tersebut menandakan ada yang tidak sejalan antara keinginan karyawan dengan tujuan dan tuntutan perusahaan. Stres kerja merupakan respon dari karyawan ketika permintaan dan beban kerja tidak sesuai dengan pengetahuan dan kemampuan yang dimiliki oleh karyawan. Beban kerja menjadi hal yang tidak dapat dihindari oleh karyawan di tengah perkembangan lingkungan kerja yang semakin dinamis. Hasil penelitian ini menunjukkan bahwa terdapat pengaruh beban kerja dan konflik kerja secara positif dan signifikan terhadap stres kerja secara simultan $F_{\text {hitung }}$ diperoleh sebesar 103,923 $>F_{\text {tabel }}$ sebesar 3,22 dengan tingkat signifikansi $0.00<0,05$, dan terdapat pengaruh beban kerja secara positif dan signifikan terhadap stres kerja secara parsial thitung sebesar 10,970>2,0195 atau nilai sig. $0,000<0,05$, dan terdapat pengaruh konflik kerja terhadap stres kerja secara parsial thitung sebesar 4,547 >2,0195 atau nilai sig. 0,000 $<0,05$. Uji determinasi menjelaskan besarnya nilai korelasi $(\mathrm{R})$ yaitu sebesar 0,914 dan terdapat pengaruh sebesar 0,835 atau $83,5 \%$ sedangkan sisanya $16,5 \%$ dijelaskan oleh faktor atau variabel lain yang tidak diteliti dalam penelitian ini.
\end{abstract}

Keyword : Beban Kerja, Konflik Kerja, Stres Kerja.

Jurnal Insitusi Politeknik Ganesha Medan 


\section{PENDAHULUAN}

Berbagai hal yang dapat menjadi sumber stres yang berasal dari pekerjaan pun dapat beraneka ragam seperti beban tugas yang terlalu berat, desakan waktu, penyeliaan yang kurang baik, iklim kerja yang menimbulkan rasa tidak aman, kurangnya informasi dari umpan balik tentang prestasi kerja seseorang, ketidakseimbangan antara wewenang dan tanggung jawab, ketidakjelasan peranan karyawan dalam keseluruhan kegiatan organisasi, frustrasi yang ditimbulkan oleh intervensi pihak yang terlalu sering sehingga seseorang merasa terganggu konsentrasinya, konflik antara karyawan dengan pihak lain di dalam dan di luar kelompok kerjanya, perbedaan sistem nilai yang dianut oleh karyawan dan yang dianut oleh organisasi dan perubahan yang terjadi yang pada umumnya memang menimbulkan rasa ketidakpastian.

Persaingan yang semakin ketat dan krisis ekonomi yang melanda seluruh negara di dunia merupakan dampak globalisasi yang harus dihadapi perusahaan saat ini. Akibat dari krisis yang berkepanjangan telah menimbulkan dampak yang sangat merugikan bagi ribuan bahkan jutaan tenaga kerja. Mereka harus rela dipindahkan ke bagian yang sangat tidak mereka kuasai dan tidak tahu berapa lama lagi mereka akan dapat bertahan atau dipekerjakan. Selain itu mereka harus menerima suatu kebijakan perusahaan yang menuntut para karyawan untuk melaksanakan tugas-tugas yang menurut pandangannya bukan merupakan bagian dari pekerjaannya. keadaan seperti ini akan membuat para pekerja di setiap level mengalami suatu tekanan, munculnya perasaan ketidakpastian karyawan dalam bekerja dan menurunnya kepuasan. Situasi inilah yang seringkali memicu terjadinya stres kerja.

\section{KAJIAN PUSTAKA}

Beban Kerja merupakan sekumpulan atau sejumlah kegiatan yang harus diselesaikan oleh suatu unit organisasi atau pemegang jabatan dalam jangka waktu tertentu. Indikator:

1. Hasil kerja

2. Objek kerja

3. Peralatan kerja

4. Tugas per tugas jabatan

Konflik Kerja merupakan ketidaksesuaian antara dua atau lebih anggota-anggota atau kelompok (dalam suatu organisasi/perusahaan) yang harus membagi sumber daya yang terbatas atau kegiatan-kegiatan kerja. Indikator:

1. Proses

2. Dua pihak atau lebih

3. Saling tergantung

4. Pertentangan mengenai objek konflik

5. Interaksi konflik

Jurnal Insitusi Politeknik Ganesha Medan 
6. Keluaran konflik

Stres Kerja merupakan suatu kondisi ketegangan yang menciptakan adanya ketidakseimbangan fisik dan psikis, yang mempengaruhi emosi, proses berpikir, dan kondisi seorang karyawan.

Indikator :

1. Faktor Pekerjaan:

a. Beban kerja

b. Desakan waktu

c. Tanggung jawab

d. Upah

e. Konflik antar tim kerja

f. Konflik antar atasan

2. Faktor Personal:

a. Frustasi

b. Masalah rumah tangga

c. Masalah finansial

3. Faktor Eksternal:

a. Perlindungan hukum

b. Lokasi rumah

c. Kejahatan

\section{Lokasi Penelitian}

\section{METODE PENELITIAN}

Penelitian ini dilakukan di PT. Agrapersada yang beralamatkan di Jl. Perintis Kemerdekaan No. 155 Dusun V Desa Sendang Rejo, Kec. Binjai, Kab. Langkat.

\section{Populasi dan Sampel}

Pada penelitian ini populasinya adalah karyawan PT. Agrapersada Medan yang berjumlah 44 orang. Sampel pada penelitian ini adalah berjumlah 44 . Semua populasi yang ada yang penarikannya adalah diambil secara sensus yakni $100 \%$ dari jumlah populasi atau disebut juga dengan metode sampling jenuh., September dan Desember.

\section{Teknik Analisis Data}

\section{Analisi Regresi Linear berganda}

Model análisis data yang digunakan dalam penelitian kali ini adalah model análisis Regresi berganda. Peneliti menggunakan Regresi linear berganda karena model ini berguna untuk mencari pengaruh antara dua atau lebih variabel bebas terhadap variabel terikat yang ada. Model persamaan regresi berganda adalah :

$$
\mathbf{Y}=\mathbf{a}+\mathbf{b}_{1} \mathbf{X}_{1}+\mathbf{b}_{2} \mathbf{X}_{2}+\mathbf{e}
$$




$\begin{array}{ll}\text { Dimana } & : \\ \mathrm{Y} & \text { : Stres Kerja } \\ \mathrm{a} & \text { : Konstanta } \\ \mathrm{b}_{1}-\mathrm{b}_{2} & \text { : Koefisien regresi } \\ \mathrm{X}_{1} & \text { : Beban Kerja } \\ \mathrm{X}_{2} & \text { : Konflik Kerja } \\ \mathrm{e} & : \text { Standard error }\end{array}$

\section{Koefisien Determinasi $\left(\mathbf{R}^{2}\right)$}

Hasil Penelitian Koefisien Determinasi $\left(\mathrm{R}^{2}\right)$ digunakan untuk mengukur proporsi atau presntasi sumbangan variabel bebas yang dteliti yaitu beban kerja $\left(\mathrm{X}_{1}\right)$ dan konflik kerja $\left(\mathrm{X}_{2}\right)$ terhadap stress kerja $(\mathrm{Y})$. Koefisien determinasi berkisar antara 0 sampai dengan 1 . Hal ini apabila $\mathrm{R} 2=0$ menunjukan ketidakmampuan variabel independen dalam mempengaruhi variabel dependen. Bila R2 mendekati 1 menunjukan kemampuan variabel independen dalam mempengaruhi variabel dependen.

\section{DISCUSSION}

\section{Hasil Penelitian}

\section{Metode Persamaan Regresi Berganda}

Persamaan regresi berganda secara umum adalah:

$$
\mathrm{Y}=-2,549+1,225 \mathrm{X} 1+0,522 \mathrm{X} 2
$$

Tabel

Hasil Uji Regresi Linear Berganda

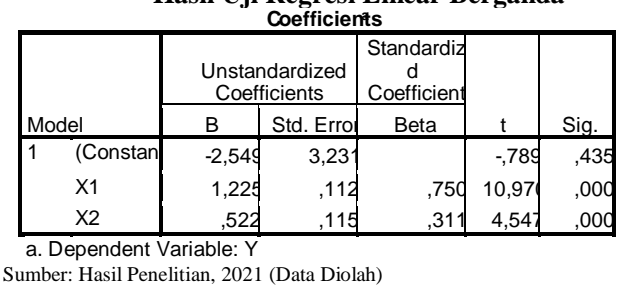

Berarti variabel beban kerja mempengaruhi stres kerja sebesar 1,225\% atau berpengaruh positif yang artinya jika beban kerja di tingkatkan sebesar $1 \%$ saja beban kerja akan meningkat sebesar 1,225\%. Sebaliknya jika beban kerja diturunkan $1 \%$ saja, maka beban kerja akan turun sebesar 1,225\%. Berarti variabel konflik kerja mempengaruhi stres kerja sebesar $0,522 \%$ atau berpengaruh positif yang artinya jika konflik kerja ditingkatkan $1 \%$ saja maka stres kerja akan meningkat sebesar $0,522 \%$. Sebaliknya jika stres kerja diturunkan $1 \%$ saja maka konfllik kerja akan turun sebesar $0,522 \%$. 


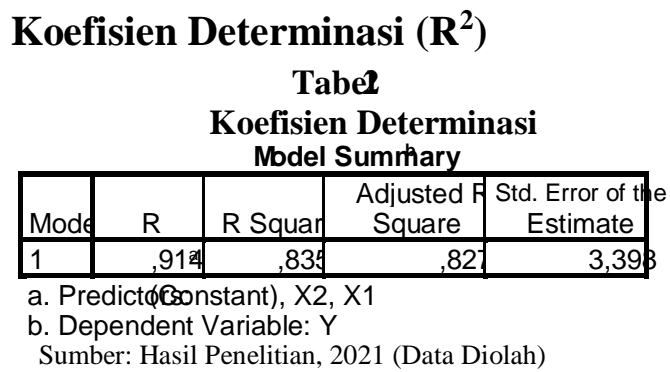

Tabel 2 menjelaskan besarnya nilai korelasi (R) antara beban kerja dan konflik kerja terhadap stres kerja yaitu sebesar 0,914 dan menjelaskan besarnya persentase pengaruh variabel beban kerja dan konflik kerja terhadap stres kerja yaitu sebesar 0,835 atau $83,5 \%$ sedangkan sisanya $16,5 \%$ dijelaskan oleh faktor atau variabel lain yang tidak diketahui dan diteliti dalam penelitian ini.

\section{Pengujian Hipotesis}

\section{Pengujian Hipotesis Secara Simultan Menggunakan Uji F}

Hasil uji signifikansi simultan dapat dilihat tabel berikut :

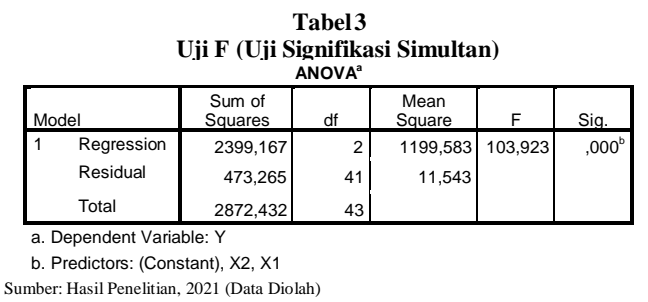

Berdasarkan Tabel 3 diatas, dapat dijelaskanbahwa nilai $F_{\text {hitung }}$ diperoleh sebesar $103,923>\mathrm{F}_{\text {tabel }}$ sebesar 3,22 dengan tingkat signifikansi $0.00<0,05$. Maka $H_{\mathrm{a}}$ diterima.

\section{Pengujian Hipotesis secara Parsial Menggunakan Uji t}

\section{a. Pengaruh $\mathrm{X}_{1}$ terhadap $\mathrm{Y}$}

Variabel beban kerja dengan nilai $t_{\text {hitung }}$ sebesar 10,970 $>t_{\text {tabel }} 2,0195$ atau nilai sig. $0,000<0,05$, maka dapat disimpulkan bahwa $H_{0}$ diterima dan $H_{\mathrm{a}}$ diterima yang berarti beban kerja berpengaruh signifikan terhadap stres kerja.

\section{b. Pengaruh $\mathrm{X}_{2}$ terhadap $\mathrm{Y}$}

Pengaruh konflik kerja dengan nilai $t_{\text {hitung }}$ sebesar 4,547 >2,0195 atau nilai sig. $0,000<0,05$, maka dapat disimpulkan bahwa $H_{0}$ diterima dan $H_{\text {a }}$ diterima yang berarti konflik kerja berpengaruh signifikan terhadap strHasil analisis 
koefisien determinasi pada penelitian ini menjelaskan bahwa besarnya nilai korelasi (R) antara beban kerja (X1) dan konflik kerja (X2) terhadap stres kerja (Y) yaitu sebesar 0,914 dan besarnya persentase pengaruh variabel beban kerja dan konflik kerja terhadap stres kerja yaitu sebesar 0,827 atau $82,7 \%$ sedangkan sisanya $18,3 \%$ dijelaskan oleh faktor atau variabel lain.

\section{Pembahasan Hasil Penelitian}

Hasil pengujian hipotesis uji $\mathrm{F}$ pada penelitian ini menjelaskan bahwa nilai

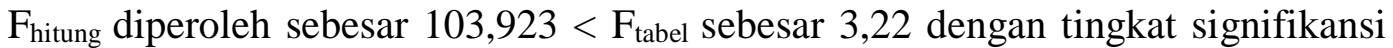
$0.00<0,05$. Maka $H_{\mathrm{a}}$ diterima, sehingga dapat dikatakan bahwa beban kerja dan konflik kerja berpengaruh terhadap stres kerja secara bersama-sama. Hasil pengujian hipotesis uji $\mathrm{t}$ pada penelitian ini menjelaskan bahwa variabel beban

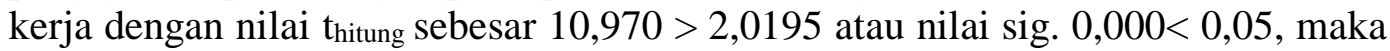
dapat disimpulkan bahwa $H_{0}$ diterima dan $H_{\mathrm{a}}$ diterima yang berarti beban kerja berpengaruh signifikan terhadap stres kerja, sedangkan pengaruh konflik kerja

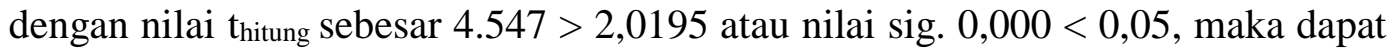
disimpulkan bahwa $H_{0}$ diterima dan $H_{\mathrm{a}}$ diterima yang berarti konflik kerja berpengaruh signifikan terhadap stres kerja.

\section{KESIMPULAN}

Berdasarkan hasil penelitian ini, dapat diambil kesimpulan sebagai berikut:

1. Hasil pengujian hipotesis uji t pada penelitian ini menjelaskan bahwa variabel beban kerja (X1) dengan nilai thitung sebesar 10,970 >1,3025 atau nilai sig. $0,000<0,05$, maka dapat disimpulkan bahwa $H_{0}$ diterima dan $H_{\mathrm{a}}$ diterima yang berarti beban kerja berpengaruh signifikan terhadap stres kerja (Y).

2. Hasil pengujian hipotesis uji t pada penelitian ini menjelaskan bahwa variabel konflik kerja (X2) dengan nilai thitung sebesar $4.547>1,3025$ atau nilai sig. $0,000<0,05$, maka dapat disimpulkan bahwa $H_{0}$ diterima dan $H_{\mathrm{a}}$ diterima yang berarti konflik kerja berpengaruh signifikan terhadap stres kerja (Y).

3. Hasil pengujian hipotesis uji $\mathrm{F}$ pada penelitian ini menjelaskan bahwa nilai $F_{\text {hitung }}$ diperoleh sebesar 103,923> $\mathrm{F}_{\text {tabel }}$ sebesar 3,22 dengan tingkat signifikansi $0.00<0,05$. Maka $H_{\mathrm{a}}$ diterima, sehingga dapat dikatakan beban kerja dan konflik kerja berpengaruh terhadap stres kerja secara bersama-sama.

4. Hasil pengujian koefisien determinasi pada penelitian ini menjelaskan besarnya nilai korelasi (R) antara beban kerja dan konflik kerja terhadap stres kerja yaitu sebesar 0,914 dan menjelaskan besarnya persentase pengaruh variabel beban kerja dan konflik kerja terhadap stres kerja yaitu sebesar 0,827 atau 82,7\% sedangkan sisanya $17,3 \%$ dijelaskan oleh faktor atau variabel lain yang tidak diteliti dalam penelitian ini. 


\section{REFERENCES}

Badeni. 2014. Kepemimpinan dan Perilaku Organisasi. Bandung: Alfabeta.

Endah. 2013. Hubungan Beban Kerja dengan Tingkat Stres Kerja pada Pekerja Sosial di Panti Sosial Tresna Werdha Budi Mulia. Skripsi. Jakarta: Universitas Islam Negeri Syarif Hidayatullah.

Fahmi, Irham. 2013. Manajemen Kepemimpinan: Teori, dan Aplikasi. Bandung: Alfabeta.

Hanggraeni, Dewi. 2011. Perilaku Organisasi: Teori, Kasus, dan Analisis. Jakarta: Lembaga Penerbit Fakultas Ekonomi UI.

Netra. 2013. Pengaruh Konflik Terhadap Stres Kerja dan Kepuasan Karyawan PT. Bank Rakyat Indonesia Kantor Cabang Denpasar. Jurnal Bali: Fakultas Ekonomi dan Bisnis Universitas Udayana.

Priyoto. 2014. Konsep Manajemen Stress. Yogyakarta: Nuha Medika.

Rivai, Veithzal. 2013. Manajemen Sumber Daya Manusia untuk Perusahaan Edisi Kedua. Jakarta: Rajawali Pers.

Santoso, Singgih. 2015. Menguasai SPSS 22. Jakarta: PT.Elex Media Komputindo

Santoso, Yussy. 2015. Organization Design and Job Analysis Edisi Revisi. Jakarta: PT.Elex Media Komputindo.

Sedanayasa, Gede. 2014. Pengembangan Pribadi Konselor. Yogyakarta: Graha Ilmu.

Sinaga, Tiahohu Maria. 2013. Analisis Pengaruh Stres Kerja Terhadap Prestasi Kerja Karyawan PT. Bardie Puritama. Jurnal. Jakarta: Universitas Kristen Krida Wacana.

Soewadji, Yusuf. 2012. Pengantar Metodologi Penelitian. Jakarta: Mitra Wacana Media.

Siagian, P Sondang. 2014. Manajemen Sumber Daya Manusia. Jakarta: Bumi Aksara.

Sujarweni, V Wiratna. 2014. Metodologi Penelitian. Yogyakarta: Pustakabarupress. 
Suryaningrum, Tri. 2015. Pengaruh Beban Kerja dan Dukungan Sosial Terhadap Stres Kerja pada Perawat RS PKU Muhammadiyah. Yogyakarta: Universitas Negeri Yogyakarta.

Thoifah. I'anatut. 2015. Statistika Pendidikan dan Metode Penelitian Kuantitatif. Malang: Madani (Kelompok Intrans Publishing).

Torang, Syamsir. 2012. Metode Riset Struktur dan Perilaku Organisasi. Bandung: Alfabeta.

Usman, Husaini 2014. Manajemen: Teori, Praktik, dan Riset Pendidikan. Jakarta: Bumi Aksara.

Wirawan. 2013. Konflik dan Manajemen Konflik: Teori, Aplikasi, dan Penelitian. Jakarta: Salemba Humanika

2015. Manajemen Sumber Daya Manusia Indonesia: Teori, Psikologi, Hukum Keternagakerjaan, Aplikasi dan Penelitian: Aplikasi dalam Organisasi Bisnis, Pemerintahan dan Pendidikan. Jakarta: Rajawali Pers

Whetten, David A. 2014. Pengembangan Keterampilan Manajemen Edisi Ketujuh. Jakarta: Indeks.

Wibowo. 2015. Perilaku dalam Organisasi Edisi Kedua. Jakarta: Rajawali Pers. 